GEOLOGICA BALCANICA, 46 (2), Sofia, Nov. 2017, pp. 87-96.

\title{
Inoceramid bivalves and calcareous nannofossils from the Coniacian of the Western Srednogorie Unit (Western Bulgaria)
}

\author{
Docho Dochev', Georgi Granchovski ${ }^{2}$ \\ ${ }^{1}$ Faculty of Geology and Geography, Department of Geology, Palaeontology and Fossil Fuels, Sofia University \\ "St Kliment Ohridski, 15 Tsar Osvoboditel Blvd, 1504 Sofia, Bulgaria; e-mail: dochev@gea.uni-sofia.bg \\ ${ }^{2}$ Geological Institute, Bulgarian Academy of Sciences, Acad. G. Bonchev Str., Bl. 24, 1113 Sofia, Bulgaria; \\ e-mail: georgi2801@geology.bas.bg
}

(Accepted in revised form: November 2017)

\begin{abstract}
The inoceramid fauna and the calcareous nannoflora of the Coniacian in two sections (Rebro and Kondel Hill) in the Western Srednogorie Unit (Western Bulgaria) have been investigated. Both of the studied sedimentary successions yielded well-preserved inoceramid bivalves. Although the calcareous nannofossil assemblages exhibit poor to very poor preservation, they are reasonably taxonomically diverse and allowed biostratigraphic interpretations to be made. In section Rebro, where the sediments of the Izvor Formation are exposed, the inoceramid fauna indicates the presence of the lower Coniacian Cremnoceramus crassus inconstans and Cremnoceramus crassus crassus/Cremnoceramus deformis deformis inoceramid zones. Based on the consistent occurrence of Broinsonia parca subsp. expansa and the absence of Micula staurophora, the sediments have been assigned to nannofossil subzone UC9c. In section Kondel Hill, the rocks of the Izvor and Melove formations crop out. Only the lowermost $\sim 5 \mathrm{~m}$ of the Melove Formation yielded inoceramids, which indicate the presence of the lower Coniacian Cremnoceramus crassus crassus/Cremnoceramus deformis deformis inoceramid Zone. The nannofossil assemblages indicate the presence of nannofossil zones UC9 (in the Izvor and Melove formations) and UC10 (in the Melove Formation), which extend from the upper Turonian (pars.) to the upper Coniacian (pars.). Base Micula staurophora/base UC10 could not be correlated with inoceramid data, however, because it was detected above the inoceramid-bearing strata.
\end{abstract}

Dochev, D., Granchovski, G. 2017. Inoceramid bivalves and calcareous nannofossils from the Coniacian of the Western Srednogorie Unit (Western Bulgaria). Geologica Balcanica 46 (2), 87-96.

Keywords: inoceramid bivalves, calcareous nannofossils, biostratigraphy, Coniacian, Western Srednogorie Unit, Western Bulgaria.

\section{INTRODUCTION}

In the Western Srednogorie tectonic unit (Western Bulgaria), joint biostratigraphic studies based on Upper Cretaceous inoceramid bivalves and calcareous nannoplankton have never previously been carried out. Inoceramid investigations in the region are scarce and for the most part outdated, relying on obsolete taxonomic concepts. Similarly, works on the Upper Cretaceous calcareous nannoflora of the Western Srednogorie Unit have depended on local zonation schemes resulting from outdated taxonomic views. Furthermore, there are some huge discrepancies between local and global nannofossil zonations, involving the order and/or age of biostratigraphically significant events. These discrepancies should be addressed and scrutinised by direct correlation of nannofossil events with macrofossil data, since all but one of Upper Cretaceous stage boundaries have been defined by macrofossils.

The present paper is an account on the inoceramid fauna and the calcareous nannoflora of the Coniacian in two sections from the Western Srednogorie tectonic unit, Western Bulgaria (Fig. 1). The main goals of the study are: (1) to examine taxonomically the inoceramid bivalves and the calcareous nannofossil assemblages; (2) to subdivide biostratigraphically the investigated sediments and refine their age; (3) to as- 
sess the applicability of global nannofossil zonations, namely the UC zonation of Burnett (1998), for this stratigraphic interval in the region; and (4) to perform direct correlation between the resultant macrofaunal and nannofloral data. The results are discussed briefly and will be published in more detail elsewhere.

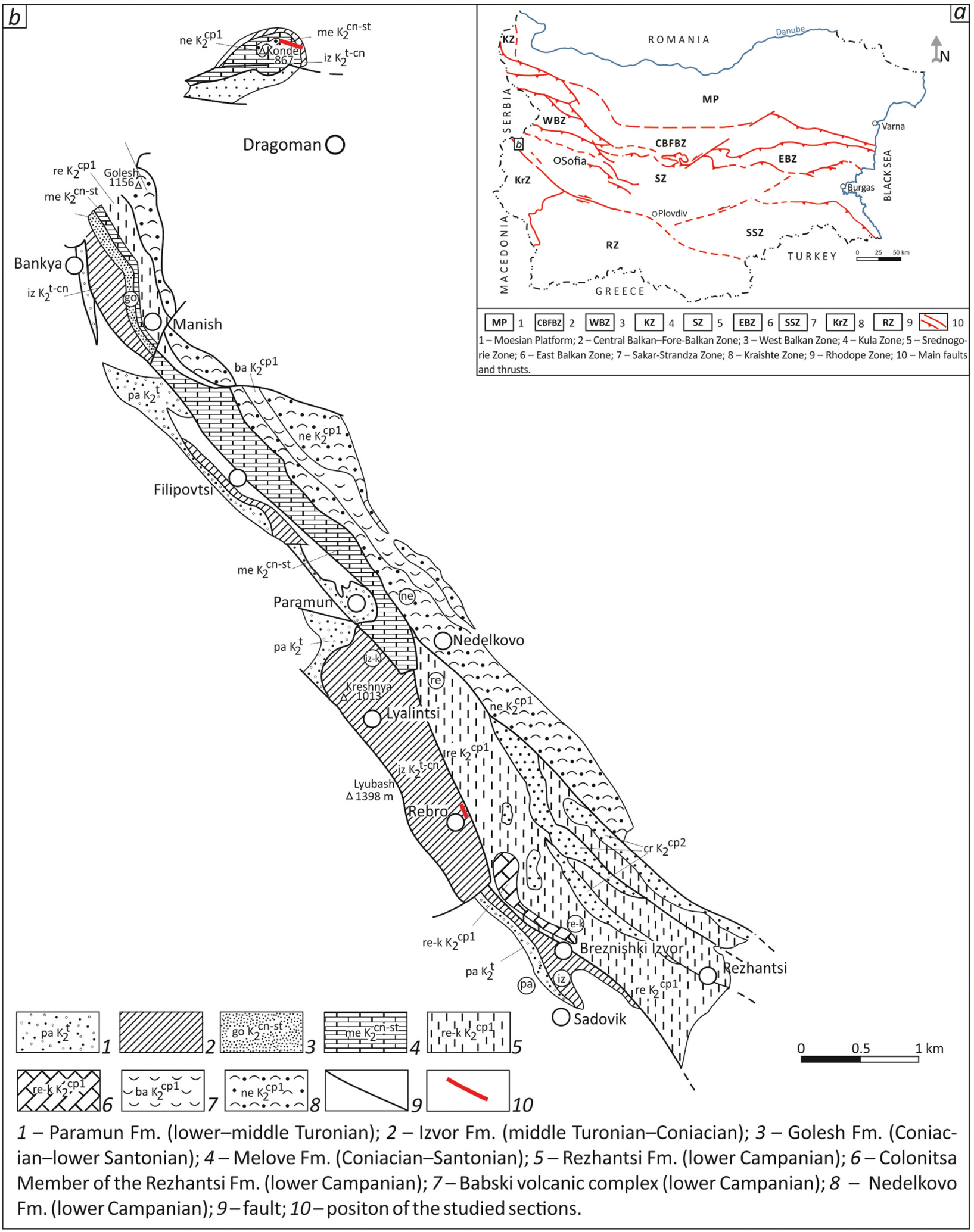

Fig. 1. Location of sections Rebro and Kondel Hill. Tectonic scheme of Bulgaria (a) after Ivanov (1998); geological map of the studied area (b) after Sinnyovsky et al. (2012; simplified). 


\section{PREVIOUS STRATIGRAPHICAL AND PALAEONTOLOGICAL INVESTIGATIONS IN THE STUDY AREA}

One of the first studies on the Upper Cretaceous rocks in the western Srednogorie Mountains was that of Bonchev (1923), who investigated the area between the towns of Breznik and Tran. He described "reddish marls and marly sandstones, silty and clayey limestones" and likened them to the Gosau-type facies. Subsequently, Vrabljanski et al. (1960) discovered Turonian-Maastrichtian sediments north of the town of Dragoman, at the vicinity of Kondel Hill. In the same year, Tzankov et al. (1960) published a more detailed study on the geology of the area between the towns of Tran and Dragoman. They combined the studied sediments into different "horizons", from the Turonian to the Maastrichtian, and adduced numerous micro- and macrofossils, including inoceramids, to support their age determinations.

The first detailed description of the sedimentary successions at Kondel Hill was provided by Jolkičev et al. (1968), who subdivided them into the Coniacian and the Santonian, based on micro- (foraminifera) and macrofossil (inoceramid bivalves and rare ammonites) evidence. Reinvestigation of section Kondel Hill was conducted by Kehayova (1970), who determined late Turonian age for the terrigenous rocks at the base of the Upper Cretaceous succession. Ganeva et al. (1978) combined the Upper Cretaceous sediments in the Slivnitsa area in different complexes, based on lithology, and subsequently Dimitrova et al. (1981) published new data on their fossil content and ages. Tzankov (1982) described and illustrated a few specimens of Coniacian inoceramid bivalves from the Western Srednogorie, collected from the areas of Breznik and Dragoman.

The first biostratigraphical studies based on calcareous nannofossils in the area north of Dragoman were carried out by Sinnyovsky and Jelev (1989). They subdivided the sediments exposed at Kondel Hill to upper Turonian-lower Coniacian and upper Coniacian-Santonian intervals. Subsequently, Sinnyovsky (1993) published nine local nannofossil zones for the Western Srednogorie, embracing the interval from the middleupper Turonian to the lower Maastrichtian. Minev et al. (1996) studied five sections of the Turonian near the town of Breznik. They proposed and correlated local zonation schemes for the Turonian, based on four fossil groups: ammonites, foraminifera, dinoflagellate cysts, and pollen and spores. Their data also allowed them to divide the Turonian into three substages. The first detailed palaeontological and stratigraphical studies based on Upper Cretaceous inoceramid bivalves in the Western Srednogorie were conducted by Dochev (2006, 2009), who indicated the presence of four inoceramid zones in the interval upper Turonian-Coniacian. Dabovski et al. (2009) used informal lithostratigraphic scheme, proposed in the geological map of
Bulgaria in scale 1:100 000 (Yanev et al., 1995; Zagorchev et al., 1995). They illustrated and correlated different Upper Cretaceous biostratigraphic schemes based on key micro- and macrofossil groups (ammonites, inoceramids, foraminifera, and calcareous nannofossils). In his monograph, Sinnyovsky (2013) summarised the nannofossil data from representative Upper Cretaceous sections and key outcrops, including different sections from the Western Srednogorie. Formal lithostratigraphic scheme for the Upper Cretaceous rocks in the Western Srednogorie was first introduced by Sinnyovsky et al. $(2012,2013)$.

\section{GEOLOGICAL SETTING}

Upper Cretaceous rocks in the Western Srednogorie Unit (sensu Ivanov, 1998; Fig. 1) are associated with Turonian-Maastrichtian volcano-sedimentary successions deposited in an intra-arc basin (Dabovski et al., 2009). In the study area, they overlie, with unconformity, Upper Jurassic-Lower Cretaceous carbonate rocks and are covered by Palaeogene sediments. Lithologically, the Upper Cretaceous in the Western Srednogorie is chiefly represented by limestones and marlstones and different types of terrigenous rocks (sandstones and conglomerates).

\section{Section Rebro}

This section is located on a small slope north of the village of Rebro (Fig. 1b). The succession mainly consists of grey, thin-bedded silty to fine-sandy marlstones, with rare thin-bedded yellowish fine-grained sandstones. Rare grey, clayey to clayey-sandy, thin- to medium-bedded limestones in the middle and upper parts of the section are observed. These marlstonedominated sediments with rare clayey limestones and sandstones have been attributed to the Izvor Formation (middle Turonian-Coniacian: Sinnyovsky et al., 2012), and this is the lithostratigraphic framework adopted herein.

\section{Section Kondel Hill}

Section Kondel Hill is situated $\sim 1 \mathrm{~km}$ to the NNW of the town of Dragoman (Fig. 1b). The deposits of two lithostratigraphic units are exposed, the Izvor and Melove formations (Sinnyovsky et al., 2012; Sinnyovsky, 2013). They lie, with angular and stratigraphic unconformity, on Lower Cretaceous (upper Valanginian-lower Hauterivian) grey silty to fine-sandy marlstones and marly limestones (Angelov et al., 2010).

The Izvor Formation (upper Turonian-lower Coniacian: Sinnyovsky et al., 2012) is represented by coarse-grained volcaniclastic sandstones, gravel-sized conglomerates, and rare grey sandy marlstones. It is overlain by a very thick sequence of strata of the Melove Formation (lower Coniacian-Santonian: Sin- 
nyovsky et al., 2012), which consists of grey to greenish and reddish marlstones and limestones.

\section{MATERIAL AND METHODS}

\section{Inoceramids}

The inoceramid bivalves recovered from section Rebro are preserved as internal moulds, with shell fragments attached in most of the specimens. The fauna predominantly consists of single right valves and rare left valves; no double-valve specimens were found. Preservation is generally very good (i.e., preserved original valve outline and well-preserved ornamentation), and only a few specimens exhibit some degree of cracking and crashing, with deformation of valve outline and rugae direction due to sedimentation processes.

The inoceramids collected from section Kondel Hill are also preserved as internal moulds, and only a small number of specimens have shell fragments still attached. The specimens are represented by mainly large- to very large-sized single valves. Most of them are complete, with original valve outline and rugae direction.

All inoceramid specimens are housed at the $\mathrm{Mu}-$ seum of Palaeontology and Historical Geology (Sofia University "St Kliment Ohridski”).

\section{Calcareous nannofossils}

Altogether, seventy-two samples (12 from section Rebro and 60 from section Kondel Hill) have been investigated for their nannofossil content. The average sampling density is one sample/0.5-1 $\mathrm{m}$ for section Rebro and one sample/2 m for section Kondel Hill.

Calcareous nannofossils were examined in simple smear-slides, made following the methodology described by Bown and Young (1998). The slides were viewed at $1250 \times$ magnification, using an oilimmersion objective lens $(100 \times)$ on a Zeiss Axioskop 40 transmitting light-microscope. Micrographs were taken with a ProgRes GT3 digital camera in cross- polarised and in plane-polarised light. They were subsequently uniformly enlarged at $2000 \times$ magnification.

Relative abundances of biostratigraphically significant species are given in the text and indicated as common (1-10 specimens/field of view), frequent (one specimen/2-50 fields of view), rare (one specimen/51-100 fields of view), and very rare (one specimen/traverse). They were estimated over three central traverses and one random to avoid overlooking of rarer taxa.

Preservation varies from poor (i.e., depauperate assemblage and/or taxonomic identification of a considerable portion of specimens is hampered by calcite dissolution or secondary overgrowth) to very poor (i.e., much of the assemblage is dissolved and/or a large proportion of specimens are difficult/impossible to identify). The predominant preservation state is poor.

For biostratigraphic subdivision of the studied sedimentary successions, Burnett's (1998) UC zonation was applied. Taxonomic concepts follow those of Perch-Nielsen (1985) and Burnett (1998). Taxonomic descriptions, with full reference list, of all taxa considered herein can be found online on Nannotax3 (http://www.mikrotax.org/Nannotax3/index. php?dir=Mesozoic).

\section{RESULTS AND DISCUSSION}

\section{Section Rebro}

\section{Inoceramids}

Inoceramid bivalves were recovered from almost all beds. The inoceramid fauna (Fig. 2) in the section is Cremnoceramus-dominated. From the lower and middle parts of the succession, the following species were obtained: Cremnoceramus crassus inconstans (Woods), Cremnoceramus rotundatus (Fiege), Cremnoceramus websteri (Mantell), Cremnoceramus transilvanicus (Simionescu), Cremnoceramus hamangiaensis (Szasz), Cremnoceramus danubiaensis (Szasz), and one specimen of Tethyoceramus kul-

Fig. 2. Lower Coniacian inoceramid bivalves from section Rebro: $a-i)$ Cremnoceramus crassus inconstans (Woods, 1912), Cremnoceramus crassus inconstans Zone: $\left(a, b\right.$ - specimen U.S, $\mathrm{K}_{2} 1659 ; c$ - specimen U.S, $\mathrm{K}_{2} 1658$; $d$ - specimen U.S, $\mathrm{K}_{2}$ 1673; $e, f$ - specimen U.S, $\mathrm{K}_{2}$ 1663; $g$ - specimen U.S, $\mathrm{K}_{2} 1694 ; h, i$-specimen U.S, $\left.\mathrm{K}_{2} 1660\right) ; j$ ) Cremnoceramus crassus crassus (Petrascheck, 1903), specimen U.S, $\mathrm{K}_{2} 1695$, Cremnoceramus crassus crassus/Cremnoceramus deformis deformis Zone; $k$ ) Cremnoceramus deformis deformis (Meek, 1871), specimen U.S, $\mathrm{K}_{2}$ 1693, Cremnoceramus crassus crassus/Cremnoceramus deformis deformis Zone; l) Tethyoceramus kulbakovi (Ivanikov, 1979), specimen U.S, $\mathrm{K}_{2}$ 1684, Cremnoceramus crassus crassus/Cremnoceramus deformis deformis Zone; $m$ ) Cremnoceramus rotundatus (Fiege, 1930), specimen U.S, $\mathrm{K}_{2}$ 1698, Cremnoceramus crassus inconstans Zone. Specimens $a-j \times 1$; specimen $k \times 0.50$; specimens $l, m \times 0.75$. 

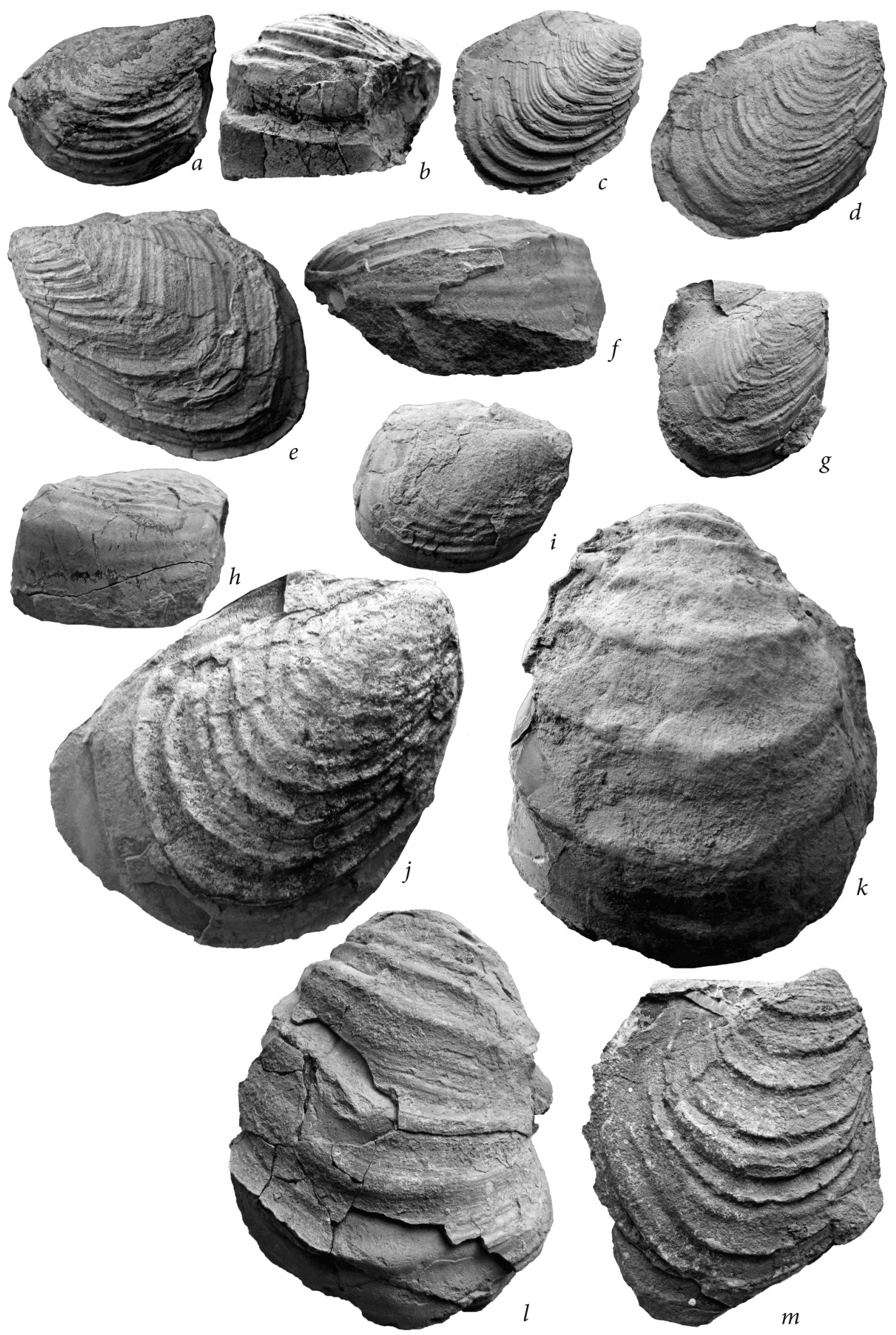
bakovi (Ivanikov). Cremnoceramus crassus crassus (Petraschek), large-sized Cremnoceramus deformis deformis (Meek), and rare Cremnoceramus crassus inconstans (Woods) were collected from the upper part of the section.

This inoceramid record has strong Coniacian affinities. Based on Cremnoceramus crassus inconstans, we indicate the Cremnoceramus crassus inconstans Zone in the lower half of the section, which is characteristic for the mid-lower Coniacian (Walaszczyk and Wood, 1998; Ifrim et al., 2014). The Cremnoceramus crassus crassus/Cremnoceramus deformis deformis Zone is indicated in the overlying strata. This zone is late early Coniacian in age (Walaszczyk, 1992; Walaszczyk and Wood, 1998; Walaszczyk and Cobban, 2000).

\section{Calcareous nannofossils}

The calcareous nannoflora recovered from section Rebro (Fig. 3) is relatively diverse, albeit poorly preserved. The assemblages are represented by common to frequent Watznaueria barnesiae and Eiffellithus eximius, closely followed by Tranolithus orionatus, Quadrum gartneri, Arkhangelskiella confusa, Quadrum svabenickae, Lucianorhabdus quadrifidus, Lithastrinus septenarius, Zeugrhabdotus biperforatus, Lucianorhabdus maleformis, Helicolithus anceps, Microrhabdulus helicoideus, and Helicolithus trabeculatus. Rare to very rare specimens of Broinsonia parca subsp. expansa were encountered in all samples. The presence of Broinsonia parca subsp. expansa and the absence of Micula staurophora indicate nannofossil subzone UC9c, which spans the interval from the upper Turonian (pars.) to the lower Coniacian (pars.) (e.g., Lees, 2008; Kędzierski, 2008).

The base of Micula adumbrata, a possible ancestor of Micula staurophora (Burnett, 1997), was detected in the uppermost Cremnoceramus crassus inconstans inoceramid Zone, just below the base of the Cremnoceramus crassus crassus/Cremnoceramus deformis deformis inoceramid Zone. This event has been shown to be diachronous through nannofossil subzones UC9a to UC9c (Lees, 2008), being oldest in the Indian Ocean, in UC9a (Lees, 2002). In Bulgaria, Micula adumbrata has so far been reported only from the upper Coniacian (nannofossil zone UC11) of NW Bulgaria (Stoykova et al., 2010).

Interestingly, Lucianorhabdus cayeuxii, although rare, is characterised by a consistent stratigraphical range throughout the whole section. Burnett (1998) used its base to draw the boundary between nannofossil subzones UC11b and UC11c. Based on correlation with the Micraster coranguinum echinoid Zone, she dated the first occurrence of Lucianorhabdus cayeuxii as late Coniacian. It has been reported, however, that in Bulgaria this species makes an appearance in the early Coniacian and clearly predates base Micula staurophora/base UC10 (e.g., Sinnyovsky, 2013, and references therein). Our data confirm the latter obser- vation (see also results for section Kondel Hill below) but do not allow us to comment on the former.

\section{Section Kondel Hill}

\section{Inoceramids}

Inoceramids (Fig. 4) were recovered only from the lowest $\sim 5 \mathrm{~m}$ of the Melove Formation. They are represented almost exclusively by very large-sized cremnoceramids that belong to Cremnoceramus crassus crassus and Cremnoceramus deformis deformis. Only one specimen was identified as Cremnoceramus crassus inconstans. The occurrence of Cremnoceramus crassus crassus and Cremnoceramus deformis deformis indicates the presence of the Cremnoceramus crassus crassus/Cremnoceramus deformis deformis Zone, which is characteristic for the upper lower Coniacian (Walaszczyk, 1992; Walaszczyk and Wood, 1998; Walaszczyk and Cobban, 2000).

\section{Calcareous nannofossils}

Five samples were taken from the volcaniclastic sedimentary rocks of the Izvor Formation. Of these, only the stratigraphically lowest sample, recovered from a $20-\mathrm{cm}$ package of greenish silty limestones, yielded somewhat diverse nannofossil assemblage. The assemblage is dominated by frequent, solution-resistant watznaueriacean taxa. Rare Eprolithus floralis, Quadrum gartneri, Quadrum svabenickae, Lucianorhabdus maleformis, Eiffellithus spp., Zeugrhabdotus diplogrammus, Lithastrinus septenarius, and Gartnerago obliquum were also observed. Braarudosphaera bigelowii is a considerable constituent of the assemblage as well. The other four samples proved to be biostratigraphically uninformative: altogether, only single, very poorly preserved, mostly unidentifiable specimens of the genera Watznaueria, Prediscosphaera, and Quadrum were encountered in each of them. The presence of Lithastrinus septenarius and the absence of Zeugrhabdotus biperforatus in the stratigraphically lowest sample indicate nannofossil subzone UC9a, which is late Turonian in age (e.g., Lees, 2008; Kędzierski, 2008). The practical lack of nannofossils in the remaining samples from the Izvor Formation renders these levels biostratigraphically indeterminate. However, based on the nannofossil data from stratigraphically higher strata (see below), it can be assumed that these virtually barren of nannoflora sediments correspond to UC9a (pars.)-UC9c (pars.) (late Turonian-early Coniacian).

Nannofossils from the overlying Melove Formation (Fig. 3) are characterised by decidedly greater taxonomic diversity and slightly better preservation. Watznaueria barnesiae and Eiffellithus eximius are the dominant taxa. Specimens of Arkhangelskiella confusa, Tranolithus orionatus, Quadrum gartneri, Lucianorhabdus quadrifidus, Zeugrhabdotus biper- 


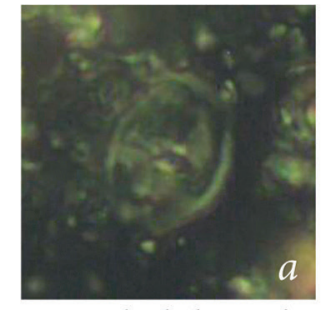

Zeugrhabdotus biperforatus Rebro, UC9c

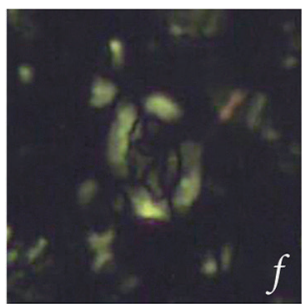

Arkh. confusa Rebro, UC9c

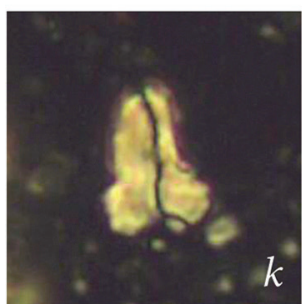

L. maleformis

Kondel H., UC9c

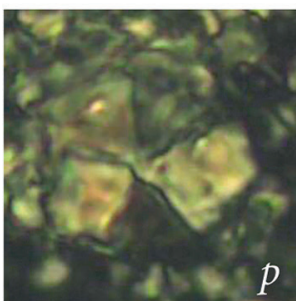

B. bigelowii

Kondel H., UC9c

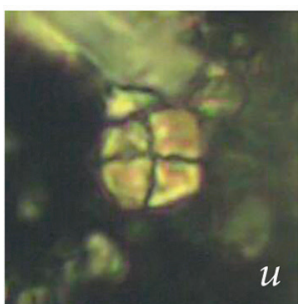

Quadrum gartneri Rebro, UC9c

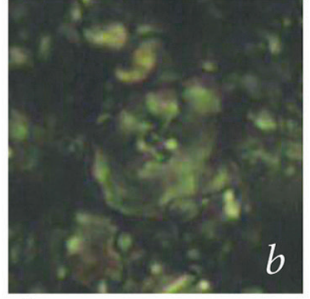

Kondel H., UC10

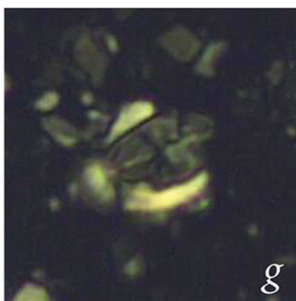

Broinsonia parca subsp. expansa Rebro UC9c

Kondel H., UC9c

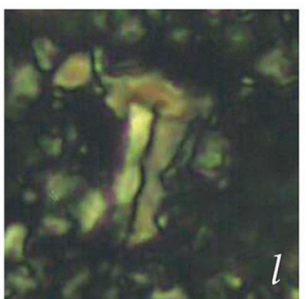

\section{Lucianorhabdus quadrifidus}

Rebro, UC9c

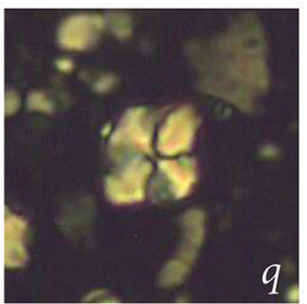

Micula adumbrata ( $r$ - rotated)

Kondel Hill, UC9c
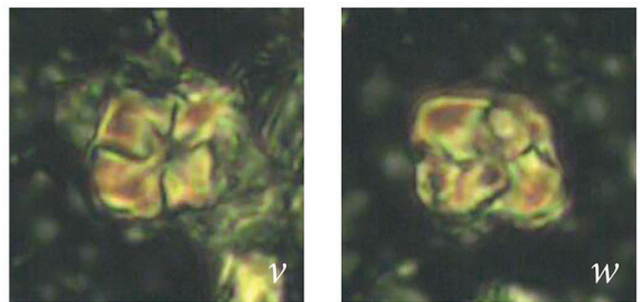

Quadrum svabenickae

Kondel H., UC10 Kondel H., UC10

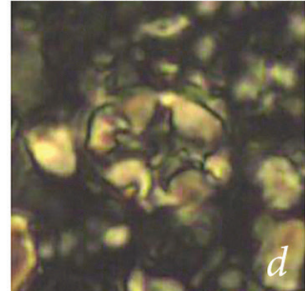

Eiffellithus eximius W. barnesiae

Kondel H., UC10 Kondel H., UC9c
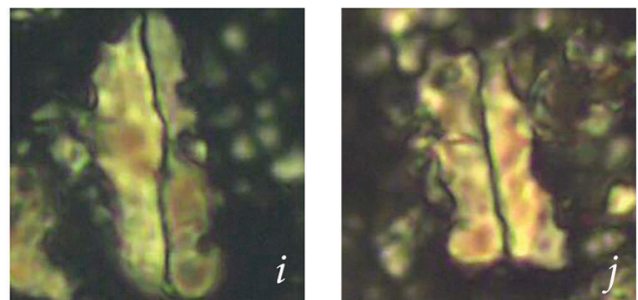

Lucianorhabdus cayeuxii

Rebro, UC9c

Kondel H., UC9c
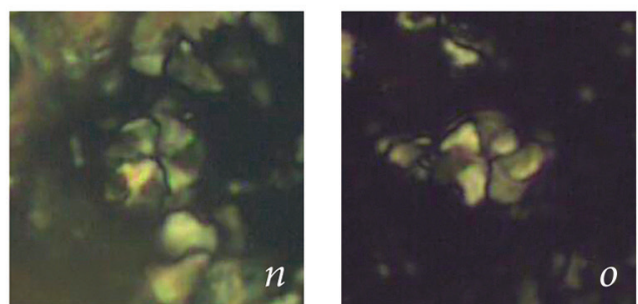

Lithastrinus septenarius

Rebro, UC9c

Kondel H., UC9c
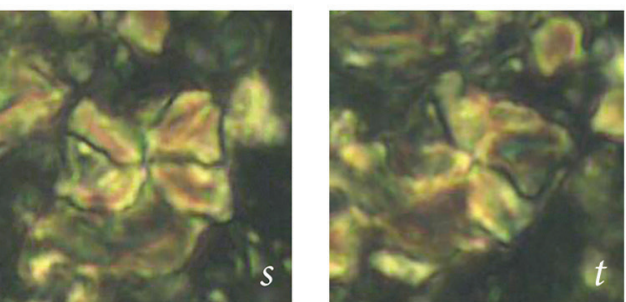

Micula staurophora ( $t$ - rotated)

Kondel Hill, UC10
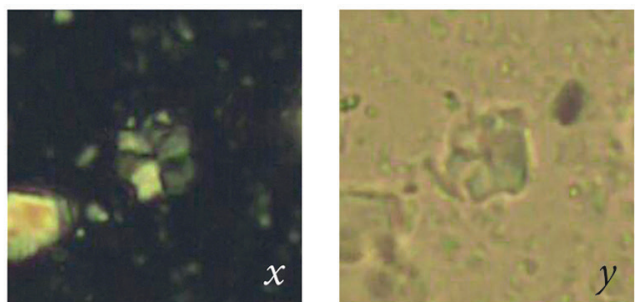

Rucinolithus hayi

Kondel Hill, UC9c (same specimen) $5 \mu \mathrm{m}$

Fig. 3. Calcareous nannofossils from the Coniacian in sections Rebro and Kondel Hill. Scale bar same for all images. Micrographs taken in cross-polarised light $(a-x)$ and in plane-polarised light $(y)$. 

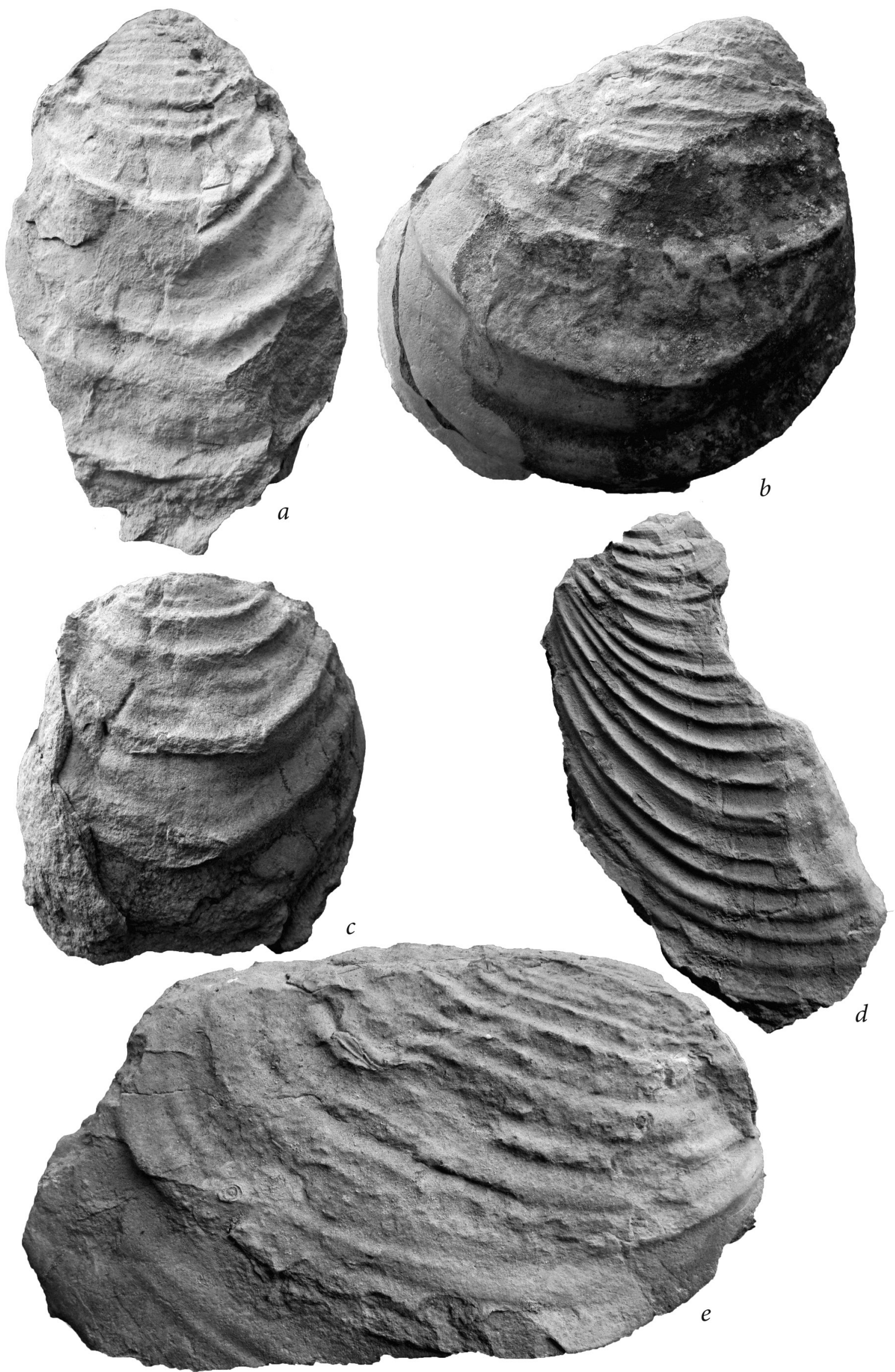
Fig. 4. Lower Coniacian inoceramid bivalves from section Kondel Hill: a, c) Cremnoceramus deformis deformis (Meek, 1871), Cremnoceramus crassus crassus/Cremnoceramus deformis deformis Zone ( $a$ - specimen U.S, K, 1687 ; $c$ - specimen U.S, $\mathrm{K}_{2}$ 1691); b, e) Cremnoceramus crassus crassus (Petraschek, 1903), Cremnoceramus crassus crassus/Cremnoceramus deformis deformis Zone ( $b$ - specimen U.S, $\mathrm{K}_{2}$ 1690; $e$ - specimen U.S, $\mathrm{K}_{2}$ 1686); d) Cremnoceramus crassus inconstans (Woods, 1912), Cremnoceramus crassus crassus/Cremnoceramus deformis deformis Zone, specimen U.S, $\mathrm{K}_{2} 1692$. All figures $\times 0.75$.

foratus, Lithastrinus septenarius, Quadrum svabenickae, Lucianorhabdus cayeuxii, Helicolithus trabeculatus, Helicolithus anceps, Eprolithus floralis, and Retecapsa spp. were frequently observed in almost all samples. Micula adumbrata and Broinsonia parca subsp. expansa, the latter of which draws the base of nannofossil subzone UC9c, are rare to very rare but exhibit reasonably consistent stratigraphical range. Base Micula staurophora, which defines the boundary between nannofossil zones UC9 and UC10, was detected well above the inoceramid-bearing strata. As no specimens of Lithastrinus grillii were encountered, UC10 extends to the top of the section. Note that $\mathrm{Lu}$ cianorhabdus cayeuxii, the base of which defines base UC11c in the upper Coniacian (Burnett, 1998), is consistently present even below base Micula staurophora (see also results for section Rebro above).

Based on these data, the studied sediments of the Melove Formation belong to UC9c (pars.)-UC10 (pars.). Their age is herein interpreted as early (pars.)late Coniacian (pars.) [the stratigraphic extent of UC10 is deduced from Burnett (1998); Lees (2008); Kedzierski (2008); Švábenická (2012); Lamolda et al. (2014)].

\section{CONCLUSIONS}

The inoceramid fauna and the calcareous nannofossils from two sections of the Coniacian in Western Bulgaria have been studied jointly for the first time. As a result, the presence of two inoceramid and two nannofossil zones has been indicated: the Cremnoceramus crassus inconstans (in section Rebro) and the Cremnoceramus crassus crassus/Cremnoceramus deformis deformis inoceramid zones (in sections Rebro and Kondel Hill), and nannofossil zones UC9 (in sections Rebro and Kondel Hill) and UC10 (in section Kondel Hill). Based on the inoceramid data, middle-late early Coniacian age is determined for the sedimentary strata exposed in section Rebro. They correlate with nannofossil subzone UC9c. In section Kondel Hill, only the lowermost $\sim 5 \mathrm{~m}$ of the Melove Formation yielded inoceramid bivalves, which indicate the late early $\mathrm{Co}-$ niacian Cremnoceramus crassus crassus/Cremnoceramus deformis deformis inoceramid Zone. Nannofossils recovered from this section allowed to indicate nannofossil subzone UC9a (late Turonian) at the very base of the Izvor Formation; the strata of the overlying Melove Formation have been assigned to UC9c (pars.)-UC10 (pars.) (early-late Coniacian).

The base of the calcareous nannofossil species Micula adumbrata has been detected within nannofossil subzone UC9c and correlates with the uppermost Cremnoceramus crassus inconstans inoceramid Zone (middle-late early Coniacian). Lucianorhabdus cayeuxii, whose base defines the base of nannofossil subzone UC11c in the late Coniacian, is characterised by continuous occurrence within UC9c, below base Micula staurophora/base UC10. These data are consistent with observations of previous authors on the local stratigraphical distribution of this taxon in Bulgaria.

\section{Acknowledgements}

We are grateful to Prof. Kristalina Stoykova (Geological Institute, Bulgarian Academy of Sciences) and two anonymous reviewers for much-appreciated constructive criticism on the manuscript.

\section{REFERENCES}

Angelov, V., Marinova, R., Grozdev, V., Antonov, M., Sinnyovsky, D., Ivanova, D., Petrov, I., Metodiev, L., Milovanov, P., Popov, A., Valev, V., Aydanliyski, G. 2010. Geological map of the Republic of Bulgaria in scale 1:50 000, Dragoman map sheet. Ministry of Environment and Water, Bulgarian Geological Survey, Sofia.

Bonchev, G. 1923. Petrographic studies in West Bulgaria. Annuaire de l'Université de Sofia 19 (1), 391-462 (in Bulgarian).
Bown, P.R., Young, J.R. 1998. Techniques. In: Bown, P.R. (Ed.), Calcareous nannofossil biostratigraphy. British Micropalaeontological Society Publication Series. Chapman and Hall/Kluwer Academic Publishers, London, 6-28.

Burnett, J.A. 1997. New species and new combinations of Cretaceous nannofossils, and a note on the origin of Petrarhabdus (Deflandre) Wind \& Wise. Journal of Nannoplankton Research 19 (2), 133-146. 
Burnett, J.A. 1998. Upper Cretaceous. In: Bown, P.R. (Ed.), Calcareous nannofossil biostratigraphy. British Micropalaeontological Society Publication Series. Chapman and Hall/Kluwer Academic Publishers, London, 132-199.

Dabovski, H., Kamenov, B., Sinnyovsky, D., Vasilev, E., Dimitrova, E., Bayraktarov, I. 2009. Upper Cretaceous geology. In: Zagorchev, I., Dabovski, Ch., Nikolov, T. (Eds), Geology of Bulgaria. Vol. II. Mesozoic geology. "Prof. Marin Drinov" Academic Press, Sofia, 303-589 (in Bulgarian, with English abstract).

Dimitrova, E.N., Ganeva, N.T., Jolkičev, N., Milanova, J.N., Nachev, I.K. 1981. Upper Cretaceous stratigraphy in Western Srednogorie. Geologica Balcanica 11 (1), 51-66.

Dochev, D. 2006. New biostratigraphic data based on inoceramid bivalves from the interval Upper Turonian-Lower Coniacian in Breznik, West Srednogorie Mountains, Bulgaria. Proceedings of the National Conference with international participation "Geosciences 2006", 61-64.

Dochev, D. 2009. Inoceramid and ammonite fauna and biostratigraphy of the Turonian-Santonian sediments in parts of the Western Srednogorie. $\mathrm{PhD}$ thesis, Sofia University "St Kliment Ohridski”, Sofia, 261 pp. (in Bulgarian, unpublished).

Ganeva, N.T., Milanova, N.Y., Nachev, I.K., Khristov, S.D. 1978. On the Upper Cretaceous sedimentology in the Slivnitsa area. Comptes rendus de l'Académie bulgare des Sciences 31 (1), 81-84.

Ifrim, C., Wiese, F., Stinnesbeck, W. 2014. Inoceramids and biozonation across the Turonian-Coniacian boundary (Upper Cretaceous) at El Rosario, Coahuila, northeastern Mexico. Newsletters on Stratigraphy 47 (2), 211-246.

Ivanov, Ž. 1998. Tectonics of Bulgaria: basic principles, tectonic zoning, and characteristics of the first-order tectonic units. Professorship thesis, Sofia University "St Kliment Ohridski”, Sofia, 579 pp. (in Bulgarian, unpublished).

Jolkičev, N., Ninov, P., Penčev, P. 1968. Über die Anwesenheit von Coniac- und Santonablagerungen im Kreis Dragoman. Review of the Bulgarian Geological Society 29 (2), 24-36.

Kędzierski, M. 2008. Calcareous nannofossil and inoceramid biostratigraphies of a Middle Turonian to Middle Coniacian section from the Opole Trough of SW Poland. Cretaceous Research 29 (3), 451-467.

Kehayova, M. 1970. Turonian sediments around DragomanWest Bulgaria. Comptes rendus de l'Académie bulgare des Sciences 23 (2), 205-207.

Lamolda, M.A., Paul, C.R.C., Peryt, D., Pons, J.M. 2014. The Global Boundary Stratotype and Section Point (GSSP) for the base of the Santonian Stage, "Cantera de Margas", Olazagutia, northern Spain. Episodes 37 (1), 2-13.

Lees, J.A. 2002. Calcareous nannofossil biogeography illustrates palaeoclimate change in the Late Cretaceous Indian Ocean. Cretaceous Research 23 (5), 537-634.

Lees, J.A. 2008. The calcareous nannofossil record across the Late Cretaceous Turonian/Coniacian boundary, including new data from Germany, Poland, the Czech Republic and England. Cretaceous Research 29 (1), 40-64.

Minev, V., Pavlishina, P., Dimitrova, E. 1996. Turonian biostratigraphy in a part of Southwestern Bulgaria. Geologica Balcanica 26 (3), 39-46.

Perch-Nielsen, K. 1985. Mesozoic calcareous nannofossils. In: Bolli, H.M., Saunders, J.B., Perch-Nielsen, K. (Eds), Plankton stratigraphy. Cambridge University Press, Cambridge, 329-426.
Sinnyovsky, D. 1993. Upper Cretaceous nannofossil zones in the Western Srednogorie area. Annual of the Higher Institute of Mining and geology 39 (1), 11-14.

Sinnyovsky, D. 2013. Upper Cretaceous nannoplankton biostratigraphy in Bulgaria. "St Ivan Rilski" Publishing House, Sofia, $80 \mathrm{pp}$.

Sinnyovsky, D., Jelev, V. 1989. Biostratigraphy of the Upper Cretaceous in Kondel Hill, Dragoman area. Annual of the Higher Institute of Mining and Geology 35 (1), 199-202.

Sinnyovsky, D., Marinova, R., Jelev, V. 2012. Upper Cretaceous lithostratigraphy in the West Srednogorie. Part I. Review of the Bulgarian geological society 73 (1-3), 105-122.

Sinnyovsky, D. Marinova, R., Jelev, V. 2013. Upper Cretaceous lithostratigraphy in the West Srednogorie. Part II. Review of the Bulgarian Geological Society 74 (1-3), 65-79.

Stoykova, K., Rabrenović, D., Ivanov, M., Mojsic, I. 2010. Stratigraphy and relations of the Upper Cretaceous of NW Bulgaria (Kula tectonic unit) and Eastern Serbia (Timok eruptive area). Bulgarian Geological Society, National Conference with international participation "Geosciences 2010", Abstracts, 80-81 (in Bulgarian).

Švábenická, L. 2012. Nannofossil record across the Cenomanian-Coniacian interval in the Bohemian Cretaceous Basin and Tethyan foreland basins (Outer Western Carpathians), Czech Republic. Geologica Carpathica 63 (3), 201-217.

Tzankov, V., Stefanov, J., Dimitrova, N., Vrabljanski, B., Enčeva, M. 1960. Géologie de Bourel et des régions avoisinantes entre Trăn et Slivnitza. Travaux sur la géologie de Bulgarie, série Stratigraphie et tectonique 1, 103-131 (in Bulgarian, with French abstract).

Tzankov, V. 1982. Les fossiles de Bulgarie. Bivalvia I. In: Tzankov, V. (Ed.), Les fossiles de Bulgarie. V. Crétacé supérieur. Grandes foraminifères, anthozoaires, gastéropodes, bivalvia. Éditions de l'Académie bulgare des Sciences, Sofia, 73-151 (in Bulgarian, with French abstract).

Vrabljansky, B., Minčev, D., Enčeva, M., Stefanov, J., Gheorghieva, M. 1960. La géologie de la région de Zabărde. Travaux sur la géologie de Bulgarie, série Stratigraphie et tectonique 1, 133-160 (in Bulgarian, with French abstract).

Walaszczyk, I. 1992. Turonian through Santonian deposits of the Central Polish Uplands; their facies development, inoceramid paleontology and stratigraphy. Acta Geologica Polonica 42 (1-2), 1-122.

Walaszczyk, I., Cobban, W.A. 2000. Inoceramid faunas and biostratigraphy of the Upper Turonian-Lower Coniacian of the Western Interior of the United States. Special Papers in Palaeontology 64, 1-118.

Walaszczyk, I., Wood, C.J. 1998. Inoceramids and biostratigraphy at the Turonian/Coniacian boundary; based on the Salzigitter-Salder Quarry, Lower Saxony, Germany, and Słupia Nadbrzeżna section, Central Poland. Acta Geologica Polonica 48 (4), 395-434.

Yanev, S., Tchounev, D., Tzankov, Tz., Tronkov, D., Sapunov, I., Tchoumatchenko, P., Khaydutov, I., Petrov, P., Nikolov, T., Dimitrova, R., Marinova, R., Rusanov, I., Gercheva, Y. 1995. Explanatory note for the geological map of Bulgaria in scale 1:100 000, Sofia map sheet. Avers ST, Sofia, 133 pp. (in Bulgarian, with English abstract).

Zagorchev, I., Kostadinov, V., Tchounev, D., Dimitrova, R., Sapunov, I., Tchoumatchenko, P., Yanev, S. 1995. Explanatory note for the geological map of Bulgaria in scale 1:100 000, Vlasotintse and Breznik map sheets. Avers ST, Sofia, 107 pp. (in Bulgarian, with English abstract). 